DOI https://doi.org/10.30525/978-9934-26-008-7.2-9

\title{
TWO-MASS ENERGOMODULAR VEHICLE LAYOUT
}

\section{Petrov L. M., Kishianus I. V.}

\section{INTRODUCTION}

Cars are an important tool for improving Ukraine's economy. In the modern period of development of the economies of the world states, the further development of the branches of the economy is closely connected with the new technologies of transport development. Reliable operation of cars with low operating costs ensures the implementation of the technological rhythm of such sectors of the economy as industry, construction, agriculture and more. Cars are included in the complex transport system of Ukraine. Such a transport system includes interaction with other models of transport, and cars are included in the chain of delivery of goods or in the chain of interaction with other modes of transport.

Cargo transported by car increases in volume much more than cargo transported by other modes of transport. Increased intensity of operation of cars, their disproportionately large growth is accompanied by averseeffects on the environment. As maintenance of the destruction of the road surface and the release of the gas component from the friction of tires on a hard surface and the formation of dust. Developed countries of the world produce cars that seem to meet modern requirements, but the operating conditions of cars are very complex and diverse, it is impossible to carry out all design improvements to the ideal.

Given the experience of economically developed countries in the constructive improvement of cars, it is possible to note with some probability that the constructive improvement of cars in Ukraine will be associated with the use of developments of advanced automotive countries. Given the experience, we proposed to consider the car in terms of the dynamics of the material system.

One of the difficulties in solving problems of dynamics of material systems (automotive systems) with two degrees of freedom is the choice of the general theorem of dynamics. In the proposed automotive system with several degrees of freedom to solve problems, which is performed using military vehicles, is much more complicated, as it requires the joint application of several general theorems and equations of dynamics. 
For the proposed automotive system, it is most convenient to use Lagrange equations of the second kind, which are a universal method of compiling differential equations of motion of material systems (automotive systems). Due to this generalization, the Lagrange equation is widely used to solve a variety of technical problems ${ }^{1}$.

\section{Analysis of existing calculation methods}

The issue of the dynamics of the calculation of a complex mechanical system was dealt with by a large number of authors. By O.V. Abdulaeva ${ }^{2}$ were made researches of works of M.S. Komarov. Extensive experience in studying the dynamics has accumulated in the developers involved in the dynamics of bridge cranes. We take as a basis from this experience multiweight dynamic models, which consist of concentrated masses connected by elastic-viscous bonds. The authors of describe the motion of such models in transient modes by systems of differential equations, based on the solution of which (taking into account the ${ }^{3}$ assumptions made) it is possible to formulate conclusions about the equality of the proposed model. In fig. Shows a threemass dynamic model of a bridge crane.

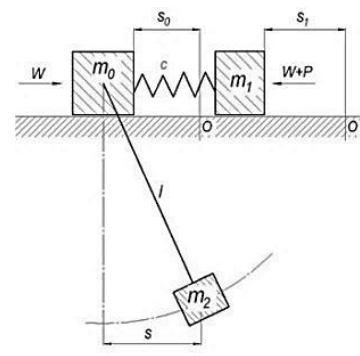

a)

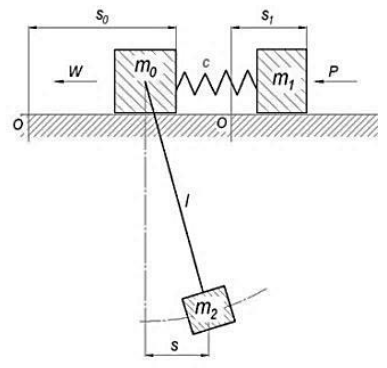

б)

Fig. 1. Three-mass dynamic model of the bridge crane: $a$-at start-up; $b$ - with braking

${ }^{1}$ Батяев Е.Ф. Теоретическая механика : электронная учебно-методическая разработка. Новосиб. гос. ун-т. Новосибирск, 2013. 466 с.

2 Абдулаева О.В. Выбор и обоснование основных параметров механизмов передвижения мостовых кранов : диссертация на соискание ученой степени кандидата технических наук, Омск 2015, 190 с. С. 26. URL: https://sibadi.org/upload/disser/abdulaeva/dissertacija.pdf.

3 Shevchenko S., Polupan E. Analysis of the influence of the mechanical characteristics of the drive during braking on dynamic loads. Вісник Східноукраӥнського національного університету імені Володимира Даля. № 2 (250) 2019, с. 126-130. 
$\mathrm{In}^{4}$ the dynamic loads in the elastic elements of the mechanism of movement of the metal structure of the crane taking into account the elastic pliability are considered. In this approach, the author investigated a two-mass single-connected dynamic model (Fig. 2).

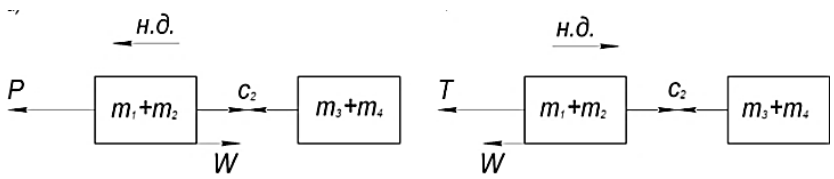

Fig. 2. Two-mass single-link dynamic bridge crane model: $a$-acceleration; $b$-braking

$\mathrm{In}^{5}$, a three-mass two-connected dynamic model was used to determine inertial loads (Fig. 3) ${ }^{6}$.

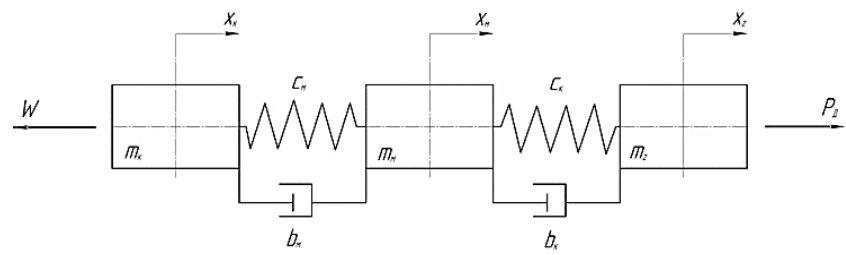

Fig. 3. Three-mass two-link dynamic bridge crane model

The method of Lagrange equations of the second kind was used to compile the equations of motion of the dynamic calculation scheme. It is used to solve a wide range of dynamics problems, and allows to obtain numerical algorithms for modeling the motion of complex systems $[9,63,64,127,132,133]$ : where $\mathrm{K}$ - kinetic energy of the system; $\mathrm{P}$ - potential energy of the system; $\Phi$ - dissipative function; $\mathrm{t}$ - time; $\mathrm{j}$ - a generalized coordinate of movement; qj - generalized speed

${ }^{4}$ Shevchenko S., Polupan E. Analysis of the influence of the mechanical characteristics of the drive during braking on dynamic loads. Вісник Східноукраїнського наиіонального університету імені Володимира Даля. № 2 (250) 2019, c. 126-130.

5 Там само

6 Жегульский В.П. Проектирование, конструирование и расчет механизмов мостовых кранов : учебное пособие / В.П. Жегульский, О.А. Лукашук ; под ред. Г.Г. Кожушко. Екатеринбург : Изд-во Урал. ун-та, 2016. 184 с., с. 13. ISBN 978-5-7996-1831-5. 
coordinate; $\mathrm{Fj}$ - Generalized force acting on the $\mathrm{j}$-th generalized coordinate.

$$
\frac{d}{d t}\left(\frac{\partial K}{\partial g_{j}}\right)-\frac{\partial K}{\partial g_{j}}+\frac{\partial P}{\partial g_{j}}+\frac{\partial \Phi}{\partial g_{j}}=F_{j},(j=1,2 \ldots . ., l)
$$

For technological machines and complexes, automobile systems inherent wide functional possibilities; the complexity and variety of means of assembling units and aggregates on the basis of which they are created; increased duration of their development long-term experimental research; construction of their models, units and aggregates and elements.

\section{The main material}

When designing a car system, research and substantiation of the interaction of mobile platforms as part of the direct car system are proposed. Such an automotive system is closely related to its mechanical and technological subsystems, which are used in the work through their interaction. To describe the automotive system, we use mathematical dependencies that directly coordinate the parameters that affect the executive bodies of the automotive system.

When developing an automotive system with new technological capabilities that do not exist in world practice, we consider it as a single system from the standpoint of solving problems in terms of theoretical mechanics with certain limitations ${ }^{7}$.

For an example in $^{8}$ elucidation of force dependences (Fig. 4), a simplified static model of the mechanism was presented. The axial force P_0, which develops the rod of the hydraulic cylinder 1, causes the axial movement of camshaft 2, which carries two helical gears 3 and 4 . The latter are coupled to the teeth of two helical gears 5 and 6 , which are mounted on the shafts of rack gears 7 and 8 with the teeth of the rail 9 . With a fixed drive gear 10, the axial movement of the camshaft 2 causes mutually opposite angular movements of the rack gears with simultaneous force elimination of gaps in all elements in contact in the closed kinematics of the circuit ${ }^{9}$.

7, Белов М.П. Теория, информационное и программное обеспечение автоматизированных электроприводных систем технологических машин и комплексов : диссертация на соискание ученой степени доктора технических наук, Санкт-Петербург. 2016 г., 435 с., с. 137-140. URL: https:/etu.ru/assets/files/ nauka/dissertacii/2016/Belov/Dis_Belov_2016.pdf.

${ }^{8}$ Там само

9 Абдулаева О.В. Выбор и обоснование основных параметров механизмов передвижения мостовых кранов : диссертация на соискание ученой степени кандидата технических наук, Омск. 2015, 190 с., с. 26. URL: https://sibadi.org/ upload/disser/abdulaeva/dissertacija.pdf. 


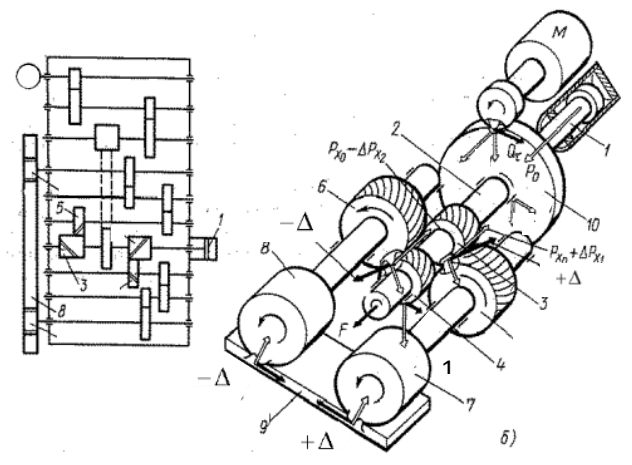

Fig. 4. Closed drive mechanism:

a) kinematic scheme; b) power dependencies

Replacement of the distributed moment of inertia of the screw by the moments of inertia concentrated on the ends is carried out according to Fig. 2.

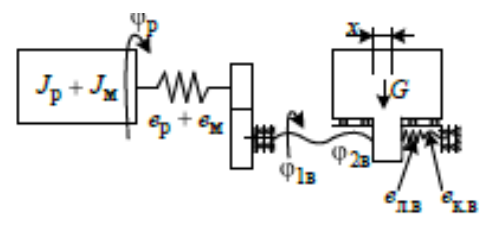

Fig. 5. Calculation scheme for determining the personal oscillation frequencies of the drive mechanism:

$J_{P}, J_{M}$ - the moment of inertia of the rotor of the engine and the clutch, as well as the moment of inertia of the gearbox reduced to the clutch; $G-$ weight, moving parts; $\mathrm{e}_{\mathrm{M}}, \mathrm{e}_{\mathrm{P}}$-the angular pliability of the coupling and the gearbox, respectively, which is reduced to the coupling shaft; $\mathrm{e}_{\text {Л.в }}, \mathrm{e}_{\mathrm{K.B}}-$ linear and torsional flexibility of the screw; $\varphi_{1 \mathrm{~B}}, \varphi_{2 \mathrm{~B}}$-the angles of rotation of the ball screw at the input gear and the nuts, respectively; $\varphi_{\mathrm{P}}-$ engine rotor rotation angle; $x$ - linear movement of the carriage

The mechanical part of the conveyors is a system with parameters distributed along the length of the conveyor: the weight of the moved load the weight and elasticity of the traction body, the force of static resistance. The presence of elastic mechanical connections contributes to the occurrence 
of oscillations, which under adverse conditions significantly increase the dynamic loads of the equipment. The motion of a system with distributed parameters is described by partial differential equations.

In ${ }^{10,11}$ to consider the physical processes that occur in the starting modes of conveyors, the real mechanical system was proposed by a simplified dynamic model in which the distributed weights and forces of elasticity and force are replaced by equivalent concentrated parameters. The author proposed a diagram of the tension of the traction body of the conveyor in the start-up mode as a basis for compiling the model. In this work, under the condition of equivalence, the equality of the tension of the traction body on the drive element of the real system by tension at the corresponding elements.

The dynamic model (Fig. 6, a) and it's calculation scheme, which is reduced to a gradual movement (Fig. 6, b).

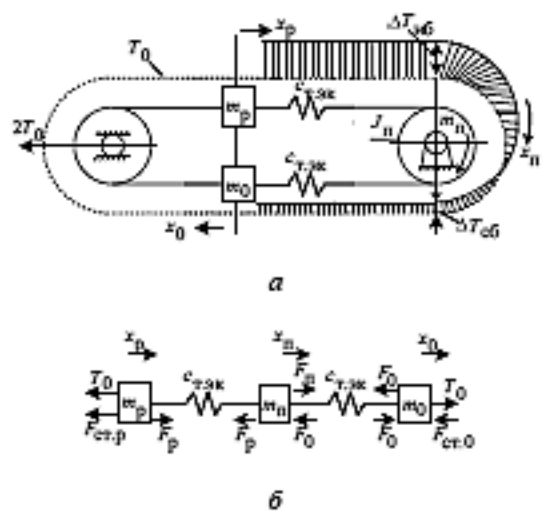

Fig. 6. Dynamic model of the moving part of the conveyor (a) and the calculation scheme, which is doc of gradual motion $(b)$

The following notations are accepted: $m_{p}, m_{0}-$ the resulting weights, respectively, the working and idle branches of the conveyor, taking into

10, Белов М.П. Теория, информационное и программное обеспечение автоматизированных электроприводных систем технологических машин и комплексов : диссертация на соискание ученой степени доктора технических наук. Санкт-Петербург. 2016 г., 435 с., с. 137-140. URL: https:/etu.ru/assets/ files/nauka/dissertacii/2016/Belov/Dis_Belov_2016.pdf.

${ }^{11}$ там само. 
account the gradually reduced weight of the tension drum; $m_{\text {п }}=\left(J_{\text {п }}+J_{\text {дв }} \cdot i_{p 2}\right) / R_{\text {п2 }}-$ the weight of the drive, which is reduced to gradual movement;

$c_{\text {T.EK }}-$ equivalent stiffness of the branches of the traction body; $x_{\Pi}, x_{\mathrm{p}}, x_{0}$ - coordinates of concentrated scales respectively $m_{\Pi}, m_{\mathrm{p}}, m_{0}$; $F_{p}=c_{\text {T.ЕК }}\left(x_{\Pi}-x_{\mathrm{p}}\right)$ i $F_{0}=c_{T . Е К}\left(x_{\Pi}-x_{0}\right)-$ respectively, the elastic forces of the working and idle branches of the traction body; $F_{\text {ст.р }}, F_{\text {ст. } 0}-$ respectively, the resulting forces of static resistance of the working and idle branches of the traction body, and $F_{\text {ст.р }}+F_{\text {ст. } 0}=F_{\text {ст }} ; F_{\Pi}=M_{\Pi}$. $i_{\mathrm{p}} / R_{\Pi}$. The motion of the drive according to the obtained dynamic model is described by a system of differential equations, which does not take into account damping.

Figures 7,8 shows the functional diagrams of the most common bridge and gantry cranes ${ }^{12}$.

Problems of automatic equalization of loading of drives of bridges and platforms and management of movement of cargo with prevention of its unrolling are solved.

Crane movement controls system to prevent unrolling of cargo. Let's perform a mathematical description and investigate the dynamic processes on the example of the control system of the bridge crane. Mechanical the trolley-suspension-load system is presented in Fig. 9, $a$.

In Fig. 9 the following ${ }^{13,14}$ designations are accepted: $\mathrm{m} 1$ - weight of the cart; $\mathrm{m} 2$ - weight of the cargo;

$l$-suspension length; $F$ - the force applied to the cart; $\varphi$ - the angle of deviation of the load from the equilibrium position. We accept the conditions: the suspension is a weightless unstretched thread, weight $m_{1}$ concentrated in the center of the scales of the cart, weight $\mathrm{m} 2$ - at the point of attachment of the load to the suspension.

12 Белов М.П. Теория, информационное и программное обеспечение автоматизированных электроприводных систем технологических машин и комплексов : диссертация на соискание ученой степени доктора технических наук. Санкт-Петербург. 2016 г., 435 с., с. 137-140. URL: https://etu.ru/assets/files/ nauka/dissertacii/2016/Belov/Dis_Belov_2016.pdf.

\footnotetext{
${ }^{13}$ Там само.

14 Там само.
} 


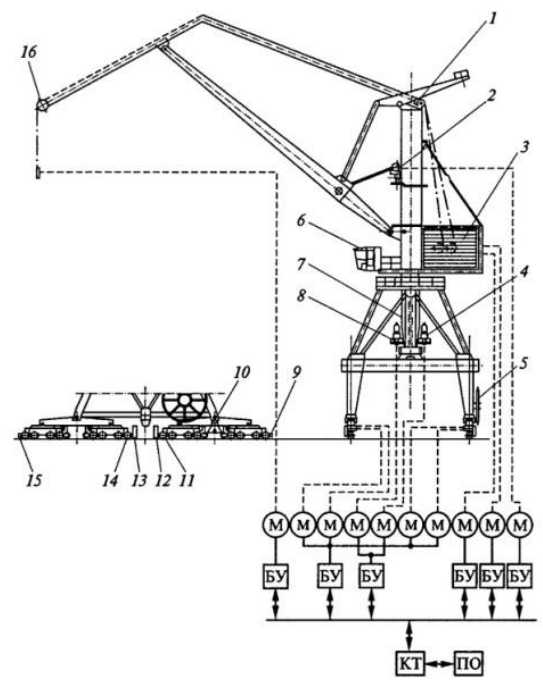

Fig. 7. Schematic representation of a gantry crane

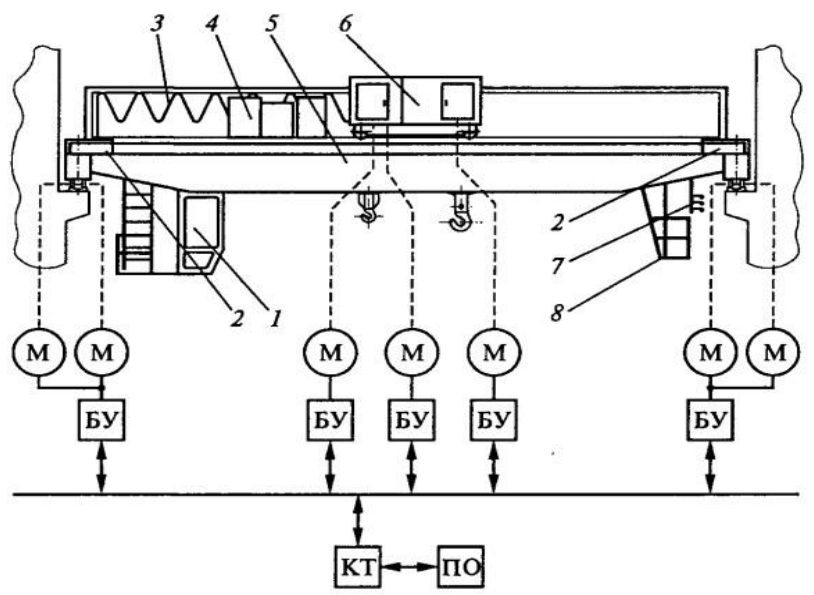

Fig. 8. Functional diagrams of bridge and gantry cranes 
Let's compose the Lagrange equation for presented mechanical system $^{15}$. In the general case for $i$-degrees of freedom of the Lagrange equation have the form: where $L=T-\Pi-$ Lagrange function; $\mathrm{T}, \Pi$ - the total stock respectively, of the kinetic and potential energy of the system; $Q_{i}-$ generalized non-conservative forces; $g_{i}, g_{i}-$ generalized coordinates and velocities.

$$
\frac{d}{d t}\left(\frac{\partial L}{\partial q_{i}}\right)-\frac{\partial L}{\partial q_{i}}=Q_{i}
$$

The author ${ }^{16}$ accepts the variables $\mathrm{x}$ and quality as generalized coordinates. The kinetic and potential energies of the system were determined by formulas:

$$
\begin{gathered}
\mathrm{T}=m_{1}+m_{2} \frac{x^{2}}{2}+m_{2} l x \varphi \cos \varphi+J_{г р} \frac{\varphi^{2}}{2} ; \\
\Pi=-m_{2} g l \cos \varphi,
\end{gathered}
$$

де $J_{\text {гр }}=l^{2} \cdot m_{2}-$ moment of inertia of the load; $\mathrm{g}=9,8 \mathrm{~m} / \mathrm{c}^{2}-$ free fell acceleration

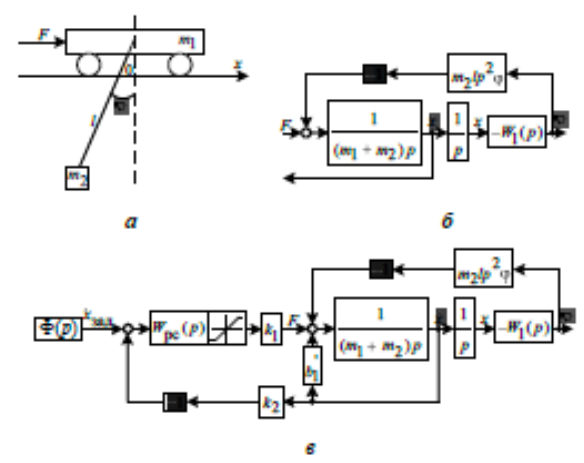

Fig. 9. Scheme of the mechanical system of trolley-suspension-load (a) and block diagrams of the mechanical system (b) and the closed control system taking into account the action of friction forces $(b)$

15 Белов М.П. Теория, информационное и программное обеспечение автоматизированных электроприводных систем технологических машин и комплексов : диссертация на соискание ученой степени доктора технических наук. Санкт-Петербург. 2016 г., 435 с., с. 137-140. URL: https:/etu.ru/assets/ files/nauka/dissertacii/2016/Belov/Dis_Belov_2016.pdf.

16 там само. 
Thus, the Lagrange function for this system is written in the form:

$$
L=T-\Pi=m_{1}+m_{2} \frac{x^{2}}{2}+m_{2} l x \varphi \cos \varphi+J_{г р} \frac{\varphi^{2}}{2}+m_{2} g l \cos \varphi
$$

Generalized forces corresponding to the accepted generalized coordinates:

$$
\begin{aligned}
& Q_{x}=F \\
& Q_{\varphi}=0
\end{aligned}
$$

Mathematical dependences are obtained (2), (3) and (4) was substituted into the Lagrange equation (1) differentiation is carried out. Due to this technique, the equations of motion were obtained:

$$
\begin{gathered}
\frac{d}{d t}\left(\frac{\partial l}{\partial x_{i}}\right)-\frac{\partial L}{\partial x_{i}}=\left(m_{1}+m_{2}\right) x+m_{2} l_{\varphi} \cos \varphi-m_{2} l \varphi^{2} \sin \varphi=F ; \\
\frac{d}{d t}\left(\frac{\partial l}{\partial \varphi_{i}}\right)-\frac{\partial L}{\partial \varphi_{i}}=m_{2} l x \cos \varphi+m_{2} l^{2} \varphi+m_{2} g l \sin \varphi=0 \\
\left(m_{1}+m_{2}\right) p^{2} x+m_{2} l p^{2} \dot{\varphi}=F ;
\end{gathered}
$$

Given the changes that have been made to (7), block diagram of the linear velocity of the trolley takes, presented on (Fig. 9, 8 ), where the following notation is accepted: $\Phi(P)$ - the shaper of the task of the speed of the cart; $x_{\text {зад }}-$ the set value of the speed of the cart; $W_{P . C}-$ transfer function of the speed regulator; $k_{1}-$ a link that reflects the electromagnetic processes of the serves to bring the electromagnetic torque of the motor to a linear force acting on the cart; $k_{2}$ - negative feedback rate.

Analyzing equation (7) obtained by the author in the study of a complex mechanical system using Lagrange equations, we can conclude that our proposed TWO-MASS ENERGOMODUAL LAYOUT OF THE VEHICLE corresponds to the concept of mobility.

Mathematical modeling of complex technical systems, as noted in ${ }^{6}$, is purposeful when the technical system can be divided into several interconnected components, each of which is in the technical system.

For construction and manipulation technology, the division into a subsystem, which describes the movement of the elements of the system and the subsystem of the hydraulic-pneumatic drive, describing the occurrence of forces between the elements of the system. This approach simplifies both the creation and analysis of mathematical models. 
The authors ${ }^{17}$ identify three main methods of modeling the motion of machines:

1. Newton-Euler equations, which allow to obtain a description of the dynamics of the machine. In this case, the centrifugal and Coriolis forces are not taken into account, which affects the accuracy of calculations and is not convenient to use for complex technical processes.

2. Generalized equations of D. Alambert. This is a difficult path, there are difficulties in its application, but displays the full picture of the dynamics of the machine.

3. Using Lagrange-Ehler equations. Such equations reflect the full picture of the dynamics of the machine and are easy to analyze.

In our work, the Lagrange equations of the coordinates of the motion of the automotive system were used, taking into account the assumptions:

the automotive system is a hinged spatial multi-chain design;

the structural elements of the automotive system are presented as absolutely rigid rods;

each structural element of the automotive system is given its own local coordinate system.

The joints in the joints are holonomic (a mechanical connection that imposes restrictions only on the position or movement of points and bodies of the automotive system) and stationary:

Mathematically, such a relationship will be represented as an equation:

$$
f_{i}\left(q_{1}, q_{2}, \ldots q_{n} \mid t\right)=0
$$

where $q_{j}-$ generalized coordinates that describe the mechanical system, $i=1 \ldots k, k$ - the number of holonomics superimposed.

Backlash and dry friction forces in the hinges are absent.

The whole physical and mathematical model of the automobile system, Fig. 10 we were divided conditionally into two parts: the technological platform and the cargo platform.

17 Оргиян А.А., Ореховский В.А. Динамика стационарных систем металлорежущих станков. Праці Одеського політехнічного університету, 2012. Вип. 1(38). С. 71-79. 


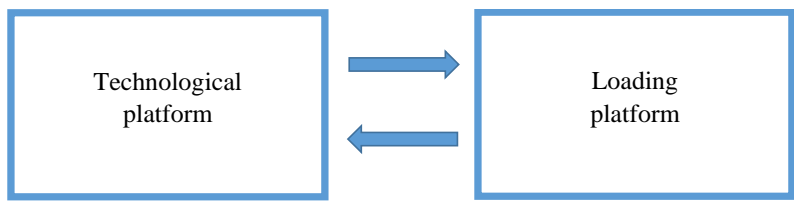

Fig. 10. Physical and mathematical model of the automobile system

Based on this, we have drawn a drawing of the relationships between the subsystems (technology platform and loading platform) which is shown on Fig. 11.

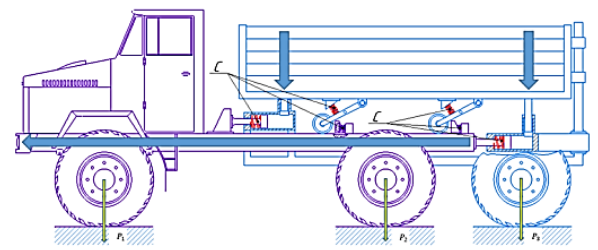

Fig. 11. Forces acting on automobile subsystems

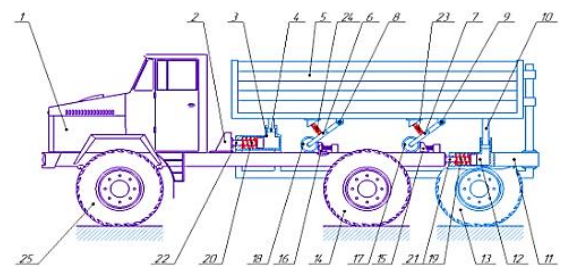

a)

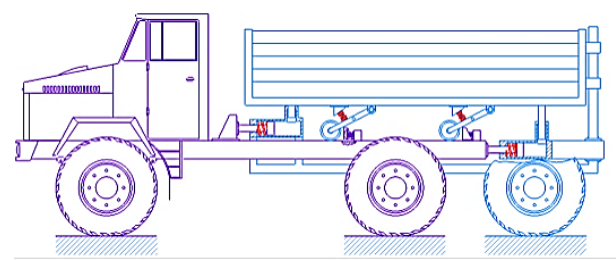

b)

Fig. 12. Scheme of a two-mass car system in a static position:

a) the car system is stationary;

b) the car system is out of equilibrium (makes low frictions) 
The technological platform includes: engine 1, driven wheels 2, 3, stops 4,5 thrust bracket 6 .

The technological platform includes: engine 1, driven wheels 25,14 , stops 15,16 , thrust bracket 2 .

1- engine; 2 - thrust bracket; 15,16 - stops; 2 - stop bracket; 13 - wheel; 5 - loading platform; 17, 18 - mobile wheels; 8, 9 - hinges; 6, 7 - levers; 15, 16 - stops; 11 - stretcher; 12 -drive; 4, 10, 19, 20, 21, 22 - piston with rod; 3 - damper, 23, 24 - compensating springs.

The two-mass automobile system consists of two platforms: a technological platform and a cargo platform. The technological platform includes: engine 1, driven wheels 2, 3, stops 4, 5, thrust bracket 6 .

The loading platform includes: wheel 13, cargo tank 5, movable wheels 17 and 18, holes 8, 9, which levers 6 and 7 and hinges 8 and 9 are connected to the cargo tank 5 . Subframe 11 with a potential drive 12 rests on the wheel 13. In the potential storage 12 there is a liquid, which in a static position balances the rod with the piston 10 and the rod with the piston 19. The rod with the piston 10 is connected to the loading platform 5. Also to the loading platform 5 with a damper 3 with a piston of 20.22 rests on a thrust bracket 2 .

This system has two degrees of freedom. Let's choose as the generalized coordinates angle $\varphi$ turning the wheel 1 from the equilibrium position (at equilibrium $\varphi=0, \mathrm{SA}=0$ и $\mathrm{S} 3=0$ ). At the beginning of motion of the automobile system we consider small oscillations, given that the angle $\varphi$ is small (Fig. $12 \mathrm{~b}$ ).

Since all the active forces acting on the system are potential (gravity and elastic force), we express the generalized force $Q \varphi$ due to potential energy $\Pi$ of the system. The motion of this mechanical system is written by one Lagrange equation of the second kind.

$$
\frac{d}{d t}\left(\frac{\partial T}{\partial \varphi}\right)-\frac{\partial T}{\partial \varphi}=Q_{\varphi}
$$

The potential energy of the system is defined as the sum of the potential energy $\Pi_{1}$, which corresponds to the forces of elasticity and potential energy $\Pi_{2}$, which corresponds to the forces of gravity.

For the zero position we take the rest position of the car system. The potential energy of the system is found as the work performed by the elastic force $\mathrm{F}$ of the spring and the forces of gravity P1, P2 and P3 during the transition of the system from the position under consideration (Fig. 12, b) at zero (Fig. 12, a). 
For the force of elasticity:

Where $\mathrm{c}$ - spring stiffness;

$$
\Pi_{1}=\mathrm{c} \cdot \lambda_{2},
$$

$\lambda$ - elongation (compression) of the spring.

For gravity:

$$
\Pi_{2}=-\mathrm{P}_{3} \cdot \mathrm{S}_{3}=-\mathrm{m}_{3} \cdot \mathrm{g} \cdot \mathrm{S}_{3},
$$

Where $\mathrm{S}_{3}$ represents the displacement of the loading platform.

For the entire automotive system (Fig. 12, b) the total potential workflow energy of this system can be represented by a formula:

$$
\Pi=\Pi_{1}+\Pi_{2}=\mathrm{c} \cdot \lambda_{2}-\mathrm{m}_{3} \cdot \mathrm{g} \cdot \mathrm{S}_{3} .
$$

Values $\lambda \mathrm{i} \mathrm{S}_{3}$ we suggest to express through an angle $\varphi$.

Determine the amount of elongation (compression) of the spring $\lambda$, taking into account that in the position of static equilibrium the spring may have some static (initial) elongation or compression $\lambda \mathrm{cm}$, which is necessary to maintain balance (in our case, to balance gravity $\mathrm{P}_{3}$, which acts on the cargo 3). When turning the wheel 1 at an angle $\varphi$ the spring gets extra to $\lambda c m$ elongation $\mathrm{S}_{\mathrm{A}}=\mathrm{R}_{1} \cdot \varphi$. So, $\lambda=\lambda \mathrm{cm}+\mathrm{S}_{\mathrm{A}}=\lambda \mathrm{cm}+$ $\mathrm{R}_{1} \cdot \varphi$. Let's depict $\mathrm{S}_{3}$ through $\varphi, \mathrm{S}_{3}=\mathrm{R}_{1} \cdot \varphi$.

Substituting all the values found in equation (2), we obtain

$$
\Pi=\mathrm{c}\left(\lambda c m+\mathrm{R}_{1} \cdot \dot{\varphi}\right)^{2}-\mathrm{m}_{3} \cdot \mathrm{g} \cdot \mathrm{R}_{1} \cdot \dot{\varphi}
$$

Let us define the generalized force $Q_{\varphi}$

$$
Q_{\varphi}=-\frac{\partial \Pi}{\partial_{\varphi}}=-c \cdot R_{1}\left(\lambda c m+R_{1} \cdot \dot{\varphi}\right)+m_{3} \cdot g \cdot R_{1}
$$

Value $\lambda \mathrm{cm}$ we find from the conditions at equilibrium, i when $\varphi=0$, should be i $Q_{\varphi}=0$. Taking into account in (4) $\varphi=0$ and $Q_{\varphi}=0$, we will get $\mathrm{cR} \mathrm{R}_{1} \lambda \mathrm{cm}=\mathrm{m}_{3} \cdot \mathrm{g} \cdot \mathrm{R}_{1}$, where

$$
\lambda \mathrm{cm}=\frac{m_{3} \cdot g}{c}
$$

Substituting in (4) the value, $\lambda \mathrm{cm}$, we obtain the formula of the generalized force:

$$
Q_{\varphi}=-\mathrm{c} \cdot \mathrm{R}_{1}^{2} \cdot \dot{\varphi}
$$

The kinetic energy $\mathrm{T}$ of an automotive system is defined as the sum of the kinetic energies $T_{1}$ of technological weight, which falls on the wheels 1 and $\mathrm{T}_{2}$ technological weight, which falls on the wheels 2 , as well as the kinetic energy $\mathrm{T} 3$ of the loading platform, i.e.:

$$
\mathrm{T}=\mathrm{T}_{1}+\mathrm{T}_{2}+\mathrm{T}_{3}
$$


Because wheels 1 and 2 revolve around axes $\mathrm{O}_{1}$ and $\mathrm{O}_{2}$, and the loading platform 3 moves gradually, the above kinetic energies are determined by formulas:

$$
\begin{aligned}
& \mathrm{T}_{1}=\frac{I_{0} \cdot \dot{\omega}_{1}^{2}}{2}, \\
& T_{2}=\frac{I_{0} \cdot \dot{\omega}_{2}^{2}}{2}, \\
& T_{3}=\frac{m_{3} \cdot V_{3}^{2}}{2}
\end{aligned}
$$

where $I_{0}$ - moment of inertia of technological weight; $\omega$ - wheel speed; $\mathrm{V}$ - speed of the technological platform,

where $I_{01}$ and $I_{02}$ wheels are determined

$$
\begin{aligned}
& I_{01}=\frac{m_{1} \cdot R_{1}^{2}}{2} \\
& I_{02}=\frac{m_{2} \cdot R_{2}^{2}}{2}
\end{aligned}
$$

where $m_{1}$ and $m_{2}-$ weight taken on wheels 1 and 2 .

Velocities $\omega$ and $v$, which are included in the equation (14), let's express through generalized speed $\varphi$. Then : $\omega_{1}=\varphi$ and $\mathrm{V}_{3}=\varphi \cdot \mathrm{R}_{1}$.

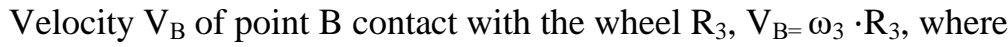

$$
\begin{gathered}
\omega_{3}=\frac{\dot{\varphi} \cdot R_{3}}{R_{2}} . \\
V_{\mathrm{B}}=\omega_{1}\left(R_{1}+R_{2}\right)=\dot{\varphi} \cdot R_{3}
\end{gathered}
$$

Substituting values $I_{01}, I_{02}, \omega_{1}, \omega_{2}, \mathrm{~V}_{3}$ in the equation (14), and then with (13), taking into account that $r_{2}=0,5 R_{2}$, we will get

$$
=\frac{m_{1} \cdot R_{1}^{2}}{2} \cdot \frac{1}{2} \cdot \dot{\varphi}^{2}+\frac{m_{2} \cdot R_{2}^{2}}{2} \cdot \frac{1}{2} \cdot \frac{\dot{\varphi}^{2} \cdot R_{1}^{2}}{r_{2}^{2}}+\frac{m_{3} \cdot \dot{\varphi} \cdot R_{3}^{2}}{2}=a_{0} \cdot \dot{\varphi}^{2},
$$

where $a_{0}=\left(m_{1}+2 m_{2}+0,25 m_{3}\right) \cdot R_{3}$

From here we find:

$$
\frac{\partial T}{\partial \varphi}=a_{0} \cdot \dot{\varphi}, \frac{d}{d t}\left(\frac{\partial T}{\partial \varphi}\right)=a_{0} \cdot \dot{\varphi}, \frac{d t}{d \varphi}=0
$$

Substituting the obtained expressions derived from equation (10) and the value of the generalized force $Q \varphi$ (6) in Lagrange's equation (1):

$$
\dot{\varphi} \cdot a_{0}=-c \cdot R_{1}^{2} \cdot \dot{\varphi}
$$




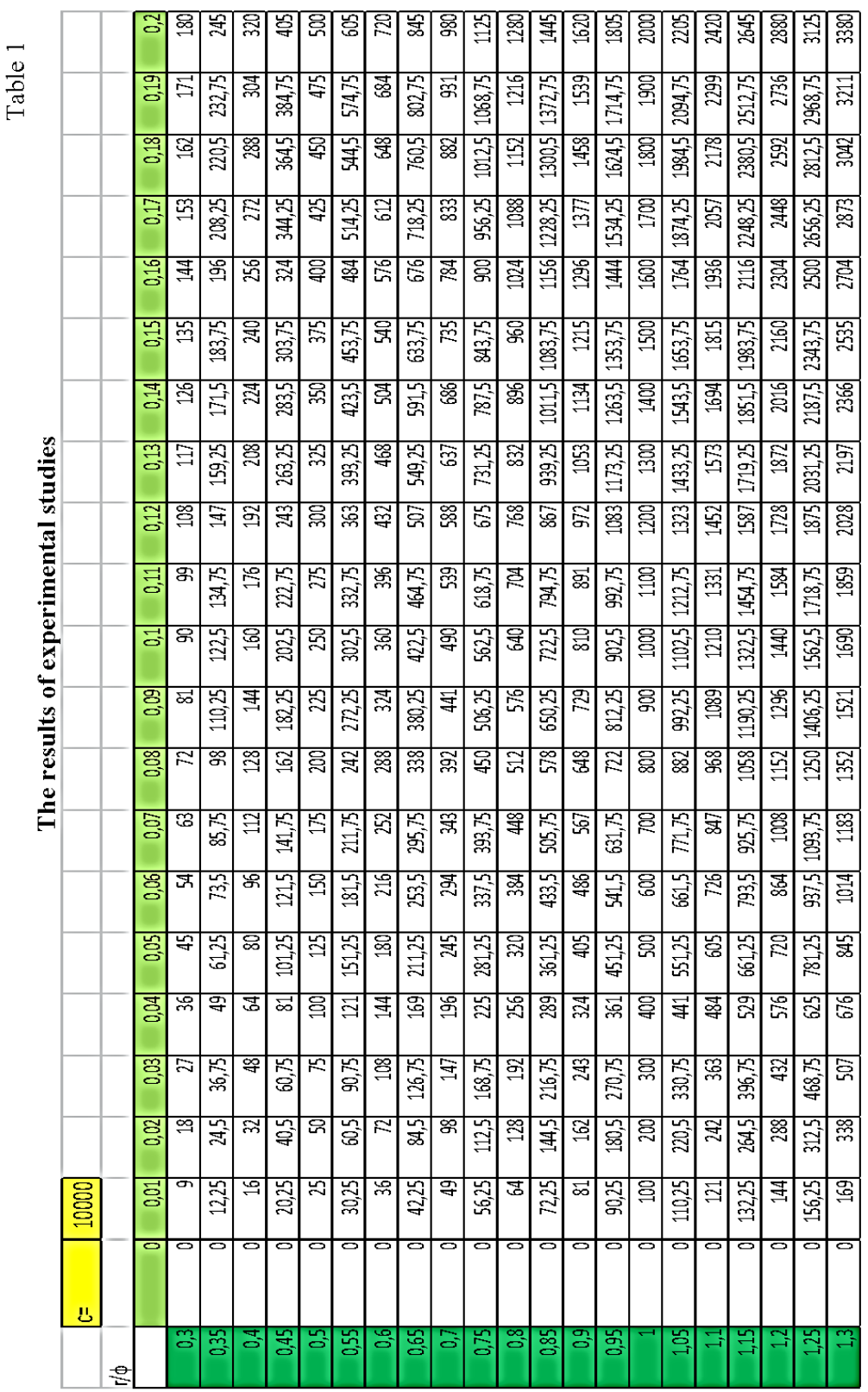


Q

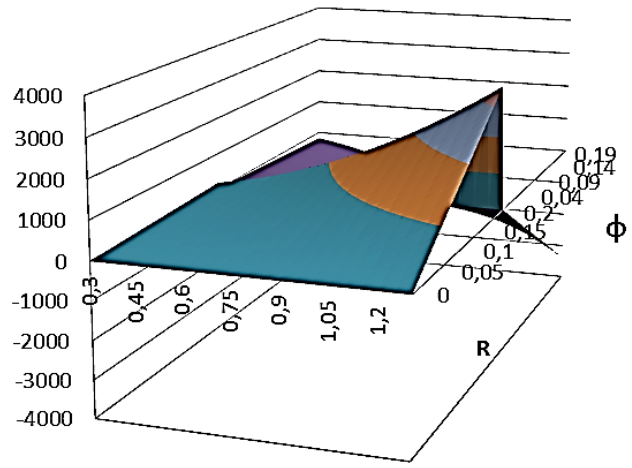

- $3000-4000$

口 2000-3000

- 1000-2000

- $0-1000$

- $-1000-0$

- $-2000-1000$

- $-3000-2000$

- $-4000-3000$

Fig. 13. Dependence of the generalized force on the radius of the wheel and its angle of rotation (tunneling effect of the movement of the two-mass energy modular layout of the vehicle)

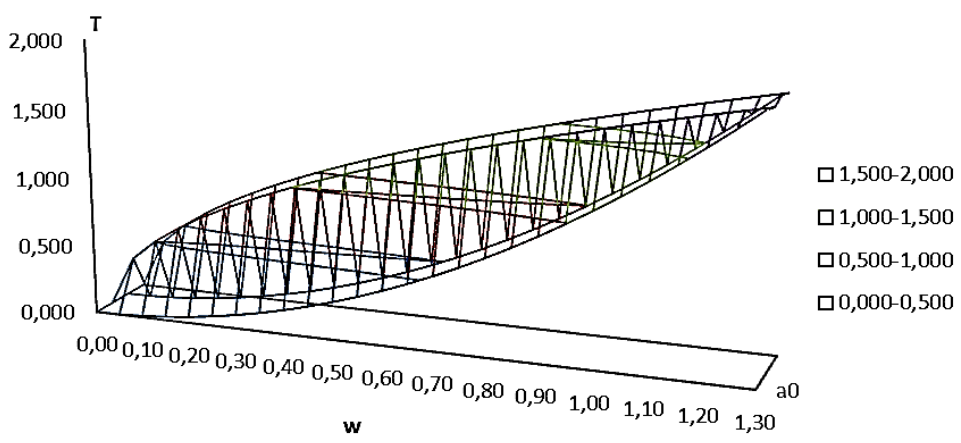

Fig. 14. Working zone (kinetic energy) of two-mass energomodular layout of the vehicle

\section{CONCLUSIONS}

1. Based on our analysis of patent and technical literature, performed theoretical researches TWO-MASS ENERGO-MODULE ARRANGEMENT of automobile system was designed.

2. Theoretical researches of TWO-MASS ENERGO-MODULE ARRANGEMENT of automobile system were made.

3. In EXEL environment were made calculations and created graphs, which are directed on visualization of regimes of work of TWO-MASS 
ENERGO-MODULE ARRANGEMENT of automobile system based on theoretical researches.

4. Due to graph of work of TWO-MASS ENERGO-MODULE ARRANGEMENT of automobile system it was found, that designed TWO-MASS ENERGO-MODULE ARRANGEMENT of automobile system works due to regime of "TONNEL EFFECT".

\section{SUMMARY}

The article presents a physical and mathematical model of a two-mass energy-modular layout of a vehicle. The method of modeling the motion of an automotive system with holonomic connections based on Lagrange equations is considered. This approach allows you to present the model of the automotive system as a combination of two platforms, power factors and mechanical connections, which ensures their combination in one workflow. Equations are made and calculations are made to change the kinetic energy at different modes of motion of the automotive system.

\section{REFERENCES}

1. Батяев Е.Ф. Теоретическая механика : электронная учебнометодическая разработка. Новосиб. гос. ун-т. Новосибирск, 2013. $466 \mathrm{c}$.

2. Shevchenko S., Polupan E. Analysis of the influence of the mechanical characteristics of the drive during braking on dynamic loads. Вісник Східноукраӥнського начіонального університету імені Володимира Даля. № 2 (250) 2019, с. 126-130.

3. Жегульский В.П. Проектирование, конструирование и расчет механизмов мостовых кранов : учебное пособие / В.П. Жегульский, О.А. Лукашук ; под ред. Г.Г. Кожушко. Екатеринбург : Изд-во Урал. ун-та, 2016. 184 с., с. 13. ISBN 978-5-7996-1831-5.

4. Белов М.П. Теория, информационное и программное обеспечение автоматизированных электроприводных систем технологических машин и комплексов : диссертация на соискание ученой степени доктора технических наук, Санкт-Петербург. 2016 г., 435 с., c. 137-140. URL: https://etu.ru/assets/files/ nauka/dissertacii/2016/Belov/Dis_Belov_2016.pdf.

5. Абдулаева О.В. Выбор и обоснование основных параметров механизмов передвижения мостовых кранов : диссертация на соискание ученой степени кандидата технических наук, Омск 2015, 
190 c., c. 26. URL: https://sibadi.org/upload/disser/abdulaeva/ dissertacija.pdf.

6. Оргиян А.А., Ореховский В.А. Динамика стационарных систем металлорежущих станков. Праці Одеського політехнічного університету, 2012. Вип. 1(38), с. 71-79.

\section{Information about authors:}

Petrov L. M.,

Candidate of Technical Sciences, Associate Professor at the Department of Automotive Engineering Odessa Military Academy 10, Fontanska doroha str., Odessa, 65000, Ukraine

Kishianus I. V., Senior Lecturer at the Department of Automotive Engineering Odessa Military Academy 10, Fontanska doroha str., Odessa, 65000, Ukraine 